\title{
IMPROVING STUDENT LEARNING RESULTS IN MATHEMATICAL LEARNING THROUGH SOMATIC, AUDITORY, VISUAL AND INTELLECTUAL APPROACH (SAVI)
}

\author{
Ovan $^{1)}$, Ramlan.M ${ }^{2)}$, Ruslan. $\mathrm{B}^{3)}$ \\ ${ }^{1,2,3}$ STKIP YPUP Makassar, Jalan Andi Tonro No 18 Makassar \\ 'Ovan_adohar@yahoo.com, ${ }^{2}$ ramlan.mm.@gmail.com
}

\begin{abstract}
This research was aimed to improve the Somatic, Auditory, Visual, and Intelectual (SAVI) approach to Grade Seven B (VII B) Bajiminasa. The Type of research used is classroom action research with classroom action research. The subject of this study was the students is class VIII Bajiminasa Makassar, South Sulawesi. The writer analyzed the data with quantitative and qualitative approaches on learning outcomes. The resulth of the study showed that the Somatic, Audotory, Visual and Intelectual (SAVI) approach was complete and student learning outomes had increased. To complete and improve in learning outcomes, presumably provide special guidance and do not experience improvement.
\end{abstract}

Keywords: Somatic, Auditory, Visual, Intelectual

\section{PENDAHULUAN}

Situasi pendidikan formal khususnya dalam mata pelajaran matematika semakin memprihatinkan. Hal ini senada dengan pendapat Ovan $(2017$; 2018) mengatakan bahwa pembelajaran matematika siswa di Indonesia belum membanggakan. Pendapat ini dibuktikan dengan keikutsertaan dalam penilaian melalui Program for International Student Assesment (PISA) disponsori oleh negara The Organization for Economic Cooperation and Development (OECD) sejak tahun 2000 sampai tahun 2015, ranking Indonesia masih berada di urutan bawah dengan rata-rata masih jauh dari skor Internasional (OECD, 2016). Hasil dari PISA 2015 menunjukkan bahwa pencapaian matematika di Indonesia menduduki peringkat ke-62 dari 70 negara dengan skor yang diperoleh adalah 386 (PISA, 2016).

Penekanan pembelajaran matematika saat ini lebih pada hafalan dan mencari satu jawaban yang benar terhadap soal-soal yang diberikan. Matematika mempunyai akar kata dari mathema yang berarti pengetahuan atau ilmu. Perkataan mathema berkembang menjadi mathematike yang berhubungan erat dengan sebuah kata lainnya yang serupa, yang mengandung arti belajar (Suherman , 2003). Menurut Hudojo (1990) Matematika adalah ilmu mengenai simbol-simbol dan hubungannya.

Menyadari hal tersebut, berbagai upaya telah dilakukan agar peserta didik tertarik untuk mempelajari matematika, salah satu upaya yang dapat dilakukan untuk menyelesaikan masalah yang dialami siswa dalam belajar. Menurut Soemanto (2003) mengemukakan bahwa Belajar adalah proses dimana tingkah laku ditimbulkan atau diubah melalui latihan atau pengalaman. Lindgren (Azhari, 1996) mengemukakan bahwa Belajar adalah suatu perubahan dalam tingkah laku sebagai hasil atau pengalaman interaksi dengan lingkungan. Sahabuddin (2000) 
mengemukakan bahwa belajar sebagai modivikasi yang tampak dari perilaku seseorang melalui kegiatan-kegiatan pengalaman-pengalamannya, sehingga pengetahuan, keterampilan dan sikapnya, termasuk penyesuain cara-caranya terhadap lingkungan yang berubah-ubah. Selanjutnya Hamalik (2001) mengemukakan bahwa belajar adalah modivikasi atau memperteguh kelakuan melalui pengalaman. Belajar merupakan suatu proses, suatu kegiatan dan bukan suatu hasil atau tujuan. Belajar bukan hanya mengingat, akan tetapi lebih luas dari itu, yakni mengalami. Upaya yang dapat dilakukan untuk menyelesaikan masalah siswa adalah dengan menggunakan pendekatan Somatis, Auditory, Visual Dan Intelektual (SAVI). Pendekatan belajar SAVI merupakan salah satu pendekatan belajar yang berusaha melibatkan seluruh kepribadian siswa baik somatis, auditory, visual dan intelektual. (Sari , Marwan , \& Melvina, 2017)

Pendekatan SAVI dapat meningkatkan hasil belajar siswa sebab pendekatan belajar SAVI berusaha agar proses pembelajaran berlangsung jangan melibatkan peserta didik secara penuh. Dalam artian proses pembelajaran yang berlangsung dapat berjalan dengan menyenangkan sehingga dapat meningkatkan hasil belajar siswa karena hanya dengan kecintaan terhadap sesuatu yang membuat kita memiliki energi yang luar biasa yang kemudian sanggup mengalirkan ide-ide kreatif. Bukan sebalikya, hanya membunuh antusiasme, membosankan, mengerutkan pikiran emosional dan menguras energi jiwa para pelajar (Ronnie, 2016).

Pendekatan SAVI merupakan pendekatan pembelajaran yang menggabungkan gerakan fisik dengan aktifitas intelektual dan penggunaan indra siswa. Johar (2011) menjelaskan pembelajaran SAVI merupakan pembelajaran yang menggabungkan gerakan fisik dengan aktifitas intelektual dan penggunaan semua indra. Unsur-unsur SAVI antara lain adalah somatis yang merupakan belajar dengan bergerak dan berbuat, auditori merupakan belajar dengan berbicara dan mendengar, visual merupakan belajar dengan mengamati, dan intelektual merupakan belajar dengan memecahkan masalah dan berpikir.

Berdasarkan uraian sebelumnya maka tujuan penelitian ini adalah mengetahui Peningkatan Hasil Belajar Siswa dalam Pembelajaran Matematika melalui Pendekatan Somatis, Auditory, Visual dan Intelektual (SAVI) Pada Siswa Kelas VIIIB SMP Bajiminasa

\section{METODE PENELITIAN}

Penelitian ini merupakan penelitian tindakan kelas (Classroom Action Research) yang dilaksanakan selama dua siklus. Penelitian tindakan kelas merupakan penelitian yang dilaksnakan secara bertahap yang disusun secara sistematis dan terarah (Arikunto, Suhardjono, \& Supardi, 2006). Pada penelitian ini, setiap siklus terdiri dari 4 tahap, yaitu: perencanaan (planning), pelaksanaan tindakan (action), pengamatan (observation) dan refleksi (reflection).

Penelitian ini dilaksanakan di kelas VIII SMP Bajiminasa dan Subyek penelitian ini adalah siswa kelas VIIIB SMP Bajiminasa sebanyak 20 orang yang terdiri dari 13 siswa laki-laki dan 7 siswa perempuan. 
Penelitian ini dilaksanakan dalam dua siklus, tiap siklus dilaksanakan sesuai tujuan yang ingin dicapai. Kedua siklus merupakan rangkaian kegiatan yang saling berkaitan, artinya pelaksanaan siklus kedua merupakan lanjutan dari siklus I. Siklus I dilaksanakan selama 3 kali pertemuan, 2 kali pertemuan digunakan sebagai proses belajar mengajar dan 1 kali pertemuan digunakan sebagai tes siklus I dan siklus II dilaksanakan selama 4 kali pertemuan, dimana 3 kali pertemuan digunakan sebagai proses belajar mengajar dan 1 kali pertemuan digunakan sebagai tes siklus II.

sumber data penelitian adalah terdiri dari guru dan siswa. Data yang diperoleh dari guru adalah informasi mengenai tingkat merangsang hubungan pikiran dan tubuh, mendengar dan berbicara, kecakapan dalam mengggambar, dan pemecahan masalah siswa dalam proses pembelajaran sebelum dikembangkannya pendekatan Somatis, Auditory, Visual dan Intelektual (SAVI). jenis data yang diperoleh adalah data kuantitatif dan data kualitatif. Data kuantitatif berupa kreativitas siswa dan hasil belajar siswa sedangkan data kualitatif berupa kreativitas siswa yang dilihat melalui lembar observasi. Data yang digunakan dalam penelitian ini adalah Hasil belajar adalah suatu hasil yang dicapai atau diperoleh siswa dalam menekuni dan mempelajari suatu mata pelajaran yang dilihat setelah diberikan tes. Intrumen penelitian diambil dari Tes hasil pekerjaan siswa dan lembar observasi.

Adapun teknik pengumpulan data dalam penelitian tindakan ini adalah dengan cara tes dan observasi. Pengelolaan data pada penelitian ini dilakukan setelah terkumpulnya data. Selanjutnya dianalisis secara kuantitatif dan kualitatif. Moleong (2007) menyatakan penelitian kualitatif lebih banyak mementingkan segi proses daripada hasil. Sedangkan Penelitian kuantitatif menurut Sugiyono (2013) adalah kejelasan masalah yang dibawa oleh peneliti dan ditunjukkan dengan data yang valid.

Indikator capaian penelitian tindakan kelas ini adalah jika siswa secara

klasikal kelas mencapai $85 \%$ dengan mencapai $\geq 70$ yang dapat digunakan di SMP Bajiminasa Makassar.

\section{HASIL DAN PEMBAHASAN}

Hasil penelitian diuraikan dalam beberapa tahap yang saling berkaitan yaitu perencanaan, pelaksanaan tindakan, pengamatan, dan refleksi. Pada pelaksanaan tindakan dilakukan dalam dua siklus, yaitu siklus I dan siklus II.

Adapun deskriptif skor hasil belajar matematika siswa pada siklus I adalah diperoleh frekuensi dengan persentase skor hasil belajar dari 20 siswa kelas VIII $_{B}$ SMP Bajiminasa Makassar tidak ada siswa yang mendapatkan nilai sangat rendah dan terdapat sebanyak 1 orang siswa (5\%) yang masuk dalam kategori rendah, 1 orang siswa (5\%) yang masuk dalam kategori sedang, 12 orang siswa $(60 \%)$ yang masuk dalam kategori tinggi, 6 orang siswa (30\%) yang masuk dalam kategori sangat tinggi. Deskripsi skor hasil belajar pada siklus 1 terlihat pada Gambar 1 berikut 


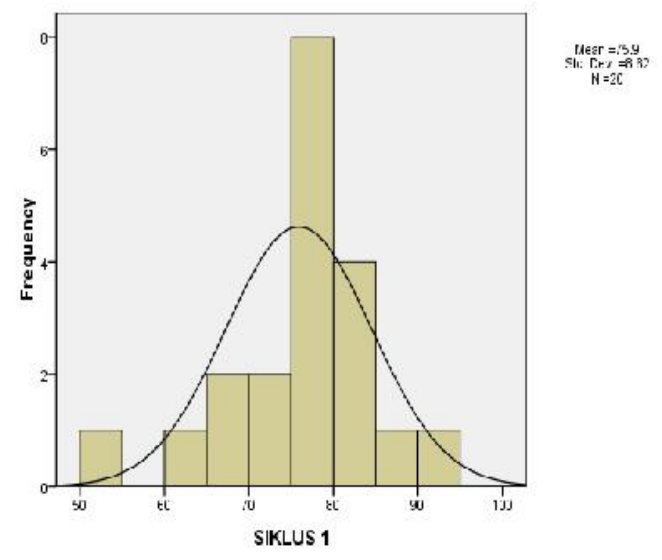

Berdasarkan Gambar 1, hasil skor rata-rata pada siklus I adalah 75,9 berada pada kategori tinggi. Berdasarkan data distrbusi frekuensi dan persentase ketuntasan hasil belajar matematika dari 20 siswa kelas VIIIB SMP Bajiminasa Makassar pada siklus I sebanyak 5 siswa yang masuk dalam kategori tidak tuntas dan sebanyak 15 siswa yang masuk dalam kategori tuntas. Menurut Sudjana (2005) pembelajaran dikatakan tuntas klasiskal apabila proporsi siswa mendapat nilai $\geq 70$ telah mencapai $75 \%$.

Data hasil belajar metematika siswa pada siklus II diperoleh melalui pemberian tes hasil belajar setelah menerapkan model pembelajaran Somatis, Auditory, Visual, dan Intelektual (SAVI). Adapun deskriptif skor hasil belajar matematika siswa pada siklus II terlihat pada Gambar 2 berikut.

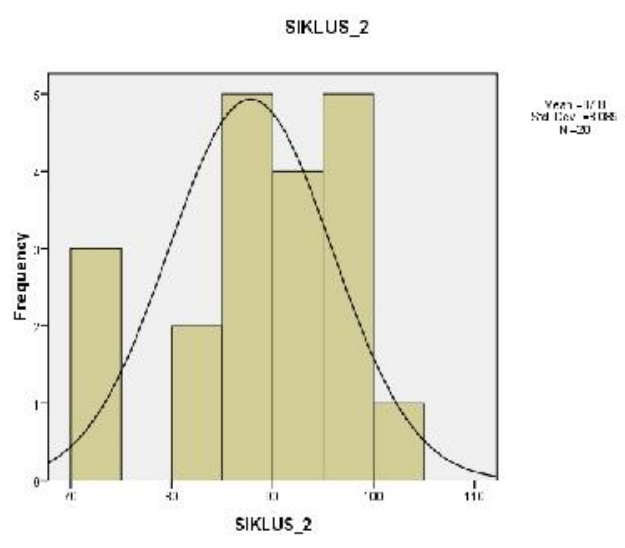

Gambar 1 Deskripsi Siklus 2

Berdasarkan Gambar 2, diperoleh frekuensi dengan persentase skor hasil belajar dari 20 siswa kelas VIIIB SMP Bajiminasa Makassar sebanyak 3 orang siswa $(15 \%)$ yang masuk dalam kategori tinggi, dan 17 orang siswa $(85 \%)$ yang 
masuk dalam kategori sangat tinggi. Dari hasil skor rata-rata pada siklus II adalah 87,8 berada pada kategori sangat tinggi.

Sedangkan apabila skor hasil belajar siswa terhadap materi tersebut dikelompokan dalam kategori ketuntasan dan ketidaktuntasan, maka dapat diperoleh distribusi frekuensi dan persentase ketuntasan hasil belajar matematika pada siklus II adalah dari 20 siswa kelas VIIIB SMP Bajiminasa Makassar pada siklus II sebanyak 19 siswa yang masuk dalam kategori tuntas dengan 95\% dan siswa yang tidak tuntas sebanyak 1 orang atau $5 \%$.

Observasi dilakukan selama proses belajar mengajar berlangsung pada saat pelaksanaan siklus I dan siklus II. pada siklus I, mulai pertemuan pertama sampai pertemuan ke empat umumnya siswa kurang antusias dalam belajar terutama dalam merespon materi pelajaran. Dari hasil pengamatan pula, pada saat proses pembelajaran kebanyakan siswa masih ragu-ragu dan takut salah bila disuruh mengerjakan soal dipapan tulis. Pada pertemuan terakhir aktifitas siswa sudah menunjukkan adanya peningkatan, hal ini dapat dilihat dari adanya siswa yang mengajukan diri untuk mengerjakan soal dipapan tulis. Sedangka dari hasil observasi yang dilakukan selama penelitian siklus II, hal-hal yang dicatat peneliti adalah (1) Perhatian siswa terhadap proses belajar mengajar pada siklus II mengalami peningkatan dibandingkan siklus I. Hal ini terlihat dengan semakin banyaknya siswa yang bertanya pada saat proses belajar mengajar berlangsung; (2) Motivasi siswa untuk mengerjakan tugas berupa latihan-latihan yang diberikan terlihat adanya kesadaran siswa menyelesaikan dan jumlah siswa yang menyelesaikan soal mengalami peningkatan. (3) Keberanian siswa untuk mengerjakan soal-soal yang diberikan dipapan tulis mengalami peningkatan dari 5 orang pada siklus I menjadi 11 orang pada siklus II. (4) Keaktifan siswa dalam proses belajar mengajar mulai terlihat pada pertemuan ke-6 dan ke-7 pada siklus II, dimana pada siklus I terdapat 4 orang saja yang mengemukakan ide/pendapat meningkat menjadi 10 orang pada siklus II. Siswa yang acuh tak acuh pada siklus I mulai memperhatikan gurunya.

Refleksi pada siklus I mengungkapkan bahwa yang menghambat peningkatan aktifitas belajar siswa adalah (1) Siswa kurang antusias dan serius dalam mengikuti proses belajar mengajar; (2) Masih tingginya gangguan dikelas yang ditunjukkan oleh banyaknya siswa yang melakukan aktivitas lain pada saat proses belajar mengajar berlangsung; (3) Kurangnya motivasi siswa dalam mengerjakan soal-soal berupa tugas karena lemahnya penguasaan siswa terhadap konsep-konsep dasar yang seharusnya mereka kuasai; (4) Masih ada siswa yang pasif bila menemui kesulitan dalam mengerjakan soal atau tugas yang diberikan. Berdasarkan hasil refleksi pelaksanaan siklus I, maka pada pelaksanaan siklus II direkomendasikan beberapa hal sebagai bahan penyempurnaan atau perbaikan, diantaranya adalah (1) Lebih mengintensifkan pelaksanaan metode pembelajaran melalui model pembelajaran Somatis, Auditory, Visual, dan Intelektual (SAVI) dalam pembelajaran untuk mencapai tujuan pembelajaran; (2) Mengurangi dan berusaha menghindari perilaku siswa yang dapat mengganggu pelaksanaan proses belajar mengajar dengan memberikan motivasi khusus dan diarahkan sedemikian mungkin, sehingga lebih giat belajar; (3) Memastikan pada saat salah seorang siswa mengerjakan soal dipapan tulis, diharapkan kepada siswa yang lainnya 
memperhatikan dan memberi tanggapan agar benar-benar terjadi interaksi antar siswa; (4) Lebih memperhatikan siswa yang masih pasif dalam menyelesaikan soal atau tugas yang diberikan.

Berdasarkan refleksi pada siklus II dapat disimpulkan bahwa perbaikan yang telah dilakukan dapat mengatasi kesulitan yang terjadi pada siklus I. Dengan demikian penerapan model pembelajaran Somatis, Auditory, Visual, dan Intelektual (SAVI) pada proses belajar mengajar dalam dua siklus pada penelitian ini dapat dijadikan model mengajar bagi SMP Bajiminasa Makassar, agar hasil belajar dapat ditingkatkan.

Penerapan model pembelajaran SAVI menyebabkan siswa tidak bermalasmalasan lagi. Dengan cara ini pula siswa dapat lebih konsentrasi dalam memperhatikan pelajaran dan aktif dalam mengikuti proses belajar mengajar di kelas karena dapat memudahkan dirinya dalam menyelesaikan soal yang diberikan, jika materinya sudah dipahami. Selain itu, dapat membuat siswa dan teman-temannya mempunyai keinginan untuk belajar bersama jika mengalami kesulitan dalam belajar. Dari pembahasan di atas dapat dikatakan bahwa hasil penelitian ini mendukung teori yang sudah ada. Penerapan model SAVI juga membuat siswa mudah dalam belajar. Pernyataan tersebut senada dengan penelitian Ersanghono (2008) yang menyatakan bahwa dengan menerapkan pembelajaran berbasis SAVI dapat memberi kemudahan untuk siswa belajar, karena siswa cenderung menggunakan aspek visual mereka saat belajar, sebagian lagi cenderung menggunakan aspek auditori dan ada pula siswa yang belajar dengan cara bergerak.

\section{SIMPULAN DAN SARAN}

Berdasarkan hasil yang diperoleh dalam penelitian ini, maka dapat disimpulkan bahwa: (1). Pembelajaran dengan model Somatis, Auditory, Visual, dan Intelektual (SAVI) terbukti dapat meningkatkan hasil belajar matematika siswa kelas VIIIB SMP Bajiminasa Makassar. (2) Terjadi peningkatan ketuntasan hasil belajar matematika siswa kelas VIIIB dari 15 orang $(75 \%)$ siswa yang berada dalam kategori tuntas pada siklus I menjadi 19 orang (95\%) pada siklus II dari skor ideal 100 dengan standar deviasi pada siklus I sebesar 8,62 dan pada siklus II sebesar 8,09. (3) Penerapan model pembelajaran Somatis, Auditory, Visual, dan Intelektual (SAVI) dalam proses pembelajaran dapat meningkatkan aktifitas belajar siswa.

Demi ketuntasan dan peningkatan hasil belajar, kiranya memberikan bimbingan khusus kepada siswa yang tidak tuntas dan tidak mengalami peningkatan sesuai KKM (72) maupun ketuntasan secara klasikal (85\%), agar bisa mencapai ketuntasan klasikal secara maksimum.

\section{DAFTAR PUSTAKA}

Arikunto, S., Suhardjono, \& Supardi. (2006). Penelitian Tindakan Kelas. Jakarta: Bumi Aksara.

Azhari, A. (1996). Psikologi Pendidikan. Semarang: Toha Putra. 
Ersanghono, \& dkk. (2008). Pembelajaran Kooperatif Tipe NHT Berbasis SAVI untuk Meningkatkan Hasil Belajar Kimia Pokok Bahasan Laju Reaksi. Jurnal Inovasi Pendidikan Kimia, 2(1), 216-223.

Hamalik , O. (2001). Proses Belajar Mengajar. Bandung: Bumi Aksara.

Hudojo, H. (1990). Teknik Belajar Matematika. Malang: IKIP Malang.

Johar, \& dkk. (2011). Meningkatkan Kemampuan Berfikir Tingkat Tinggi pada PelajaranAudiotory, Visual, Intelektual (SAVI). Jurnal Pendidikan MIPA, $3(2), 21-22$.

Moleong, L. J. (2007). Metode Penelitian Kualitatif. Bandung: Remaja Rosdakarya. Bandung: Remaja Rosdakarya.

OECD. (2016, 12 19). PISA 2015 Results in Focus. Diambil kembali dari OECD Publicing: http://dx.doi.org/10.1787/9789264190511-en (04 Oktober 2016)

Ovan, \& Nugroho, S. E. (2017). Analisis Kemampuan Literasi Matematika ditinjau dari Metakognisi Siswa Pada Model PISA-CPS. UJMER, 6 (1), 93-98.

Ovan, Waluya, S. W., \& Nugroho, S. E. (2018). Analysis mathematical literacy skills in terms of the students'metacognition on PISA-CPS model. ICMSE, $1(1), 1-6$.

PISA. (2016). What Students Know and Can Do, Student Performance in Mathematics, Reading and Science Volume I.

Ronnie, M. D. (2016). The Power of Emosional \& Adversity Qoutien for Teachers. Jakarta: Hikmah.

Sabaruddin. (2000). Mengajar dan Belajar. Makassar: UNM.

Sari , W., Marwan , A., \& Melvina. (2017). Pengaruh Pendekatan Savi (Somatic, Auditory, Visual, And Intelectual ) Dengan Menggunakan Media Education. Jurnal Ilmiah Mahasiswa (JIM) Pendidikan Fisika., 1(4), 108113.

Soemanto , W. (2003). Psikologi Pendidikan. Jakarta: PT. Rineka Cipta.

Sudjana. (2005). Metoda Statistika. Bandung: Tatsito.

Sugiyono. (2013). Metode Penelitian Kombinasi (Mixed Methods). Bandung : Alfabeta.

Suherman , E. (2003). Strategi Pembelajaran Matematika Kontemporer. Bandung: JICA UPI. 